\title{
6 Personal and academic narratives of exiled and displaced scholars
}

\author{
Magdalena Kmak and Mehrnoosh Farzamfar
}

\section{Introduction}

More often than other refugees, exiled scholars publicly reflect on their displacement as a condition of political or cultural significance. While some are silent about their experiences or even refuse to be called refugees or 'exiled intellectuals', ${ }^{1}$ others recognise the impact of exile, displacement, or migration experience on their academic work and thought. In this chapter, we analyse four interviews with currently displaced legal scholars in the light of a greater body of scholarship and archival materials. The primary focus of the archival materials is on scholars with a background in legal studies or legal education, who were exiled from Nazi Germany in the 1930s and 1940s.

In this chapter, we take the experience of displacement as the main point of departure. Hannah Arendt has underlined the importance of experience for scientific work:

I have always believed that, no matter how abstract our theories may sound or how consistent our arguments appear, there are incidents and stories behind them, which, at least for ourselves, contain as in a nutshell the full meaning of whatever we have to say. Thought itself [...] arises out of the actuality of incident, and incidents of living experience must remain its guideposts by which it takes its bearing if it is not to lose itself. ${ }^{2}$

Exile and displacement, for sure, create a unique living experience. Following what Hannah Arendt has discussed, the impact of exile experience on scholarly changes has been accounted for in the literature, both in the first ${ }^{3}$ and in the second generation of exile studies. ${ }^{4}$ The latter more comprehensively covers the effects of exile on the development of science and knowledge. This approach considers, for instance, the need to stop treating the transfer of knowledge under exile or displacement as one-sided or static. Instead, these conditions need to be perceived as a formative and dynamic process. ${ }^{5}$

The work of Tuori, focusing on German-Jewish scholars of Roman law in exile in the UK, shows that the experience of exile and immersion in a new academic culture contributed significantly to the development of the idea of a shared European legal culture. ${ }^{6}$ A similar impact could be seen in the work of

DOI: $10.4324 / 9781003092421-9$ 
the Institute of Social Research (the Frankfurt School) in exile in the US. ${ }^{7}$ Kerstin von Lingen shows how the exile situation offered a 'global intellectual space' that, coupled with the experience of exile, violence, and anti-Semitism, contributed to the development of the concept of crimes against humanity. ${ }^{8}$ As she writes, the exiled scholars 'were deeply affected by personal experience of persecution and aimed to find a legal solution to bring the criminals to trial'. ${ }^{9}$

Despite the different circumstances of exile and refuge faced by contemporary displaced scholars and scholars exiled in the 1930s and 1940s, as well as the differing conditions of scientific work in contemporary western academia, common threads emerge from the research materials. This common ground encompasses issues such as the conditions of displacement and experience of asylum and refuge procedures; human rights, justice, and the need to act; development of the scholar's academic career and scholarly identity; and the relationship with the scholar's home country. In addition to these common threads, precarity comes to the fore as a condition of scholars currently displaced and is often discussed in light of precarity of contemporary academic work more generally. ${ }^{10}$

Therefore, in this chapter, we strive towards a more comprehensive understanding of the experience of displaced scholars and the role of this experience in the development of legal thought. The research on intellectual change in the work of legal scholars is particularly interesting, as historically, émigré lawyers and legal scholars faced particular difficulties in finding employment. ${ }^{11}$ This happened due to the lack of resemblance between German and US legal traditions and education. Indeed, as Graham has pointed out, by the end of the 1930s, placing foreign jurists in US law schools was nearly impossible, ${ }^{12}$ and most of them faced the need to rebrand themselves or to start afresh. Such difficulties often led to scientific change and the development of new disciplines. ${ }^{13}$

This chapter focuses on the interviews conducted with four scholars in the late autumn of 2018. Three of them are legal scholars and one works with topics related to law. These scholars are currently at different European universities. Some have the support of Scholars at Risk (or similar networks), and some are at risk, but they have found scientific positions without any institutional support. During the interviews, scholars were asked to reflect on the impacts of their exile experience on the direction and focus or the result of their research. The interview questions focused on previous and current subjects of study, topics they are working on now, any changes in their research fields, research topics, or research methods after the scholars started their research at the university they are employed now, their current and future work plans, and new projects or scholarly ideas. ${ }^{14}$

In this chapter, first we discuss the theoretical questions related to the research on exile experience and experience of displacement. Then, we investigate three distinct topics, which run through both the historical and contemporary biographies. The first topic is the conditions of exile and experiences of displacement. The second topic is the development of one's academic career and scholarly identity, and the third topic is the questions of justice, human rights, and the need to act. Even though our focus is on the 
contemporary displaced scholars, the experience of the historical figures serves as the main reference point for discussion; hence, we quote some of their accounts at the beginning of each part of analysis in section three. In the final section, we conclude the discussion.

\section{Theoretical questions related to research on experience of displacement}

The impact of the conditions of displacement on scholarly work is widely recognised in exile and migration studies. ${ }^{15}$ This includes the need to work in a foreign language and within a different scholarly tradition, to accept any position offered, and consequently to abandon the prestige of one's academic position at home university. It also often involves the need to change discipline or to start a degree from scratch. In short, these circumstances have exposed the exiled scholars to new conditions of doing science, a situation that they responded to differently. In this regard, Franz L. Neumann has identified three degrees of involvement for exiled scholars in US academia, pointing out that the most difficult but at the same time the most rewarding one was the integration of old traditions into new experiences. ${ }^{16}$ The best setting for this response was a mixed environment of native and refugee scholars, where émigrés could serve as 'bridges' between the old and the new. ${ }^{17}$

It is clear, however, that the experience of exile does not automatically create the conditions to produce new ideas and knowledge. ${ }^{18}$ In fact, this knowledge production requires certain personal attributes, coupled with certain suitable legal and socio-economic conditions. Asli Vatansever highlights:

Theoretically as well as empirically in view of some specific examples, the experience of exile as well as the nomadic/exilic state of mind signifying a discursive and epistemological breakaway from the conventional modes of thinking are assumed to be enriching in terms of intellectual subjectivity. The key in this respect lies, however, in the way the individual engages with the changing parameters of his/her mode of being in the world and copes with the loss of his/her former coordinates in life. ${ }^{19}$

The approach needed could be summarised in the words of one of the interviewed displaced scholars (Scholar 3): 'I am not comfortable in my own comfort zone.' It seems, however, that the individual's relationship to pain ${ }^{20}$ and their recognition of loss and deprivation foster their creation of new ideas and identities in exile. ${ }^{21}$ To be sure, the past impact of exile and refuge on scholarly thinking is widely recognised in exile scholarship. As Alfons Söllner puts it:

If emigration is understood as breaking the social ground of doing science and as the beginning of the transfer of ideas and cultural substance, then it can be assumed that the social rooting in the new context leaves traces behind in the new scientific environment of the country of arrival - sometimes so the émigrés realize it and sometimes their influence is seen only later. ${ }^{22}$ 
Many scholars of various disciplines, such as Hannah Arendt, Paul Tillich, Franz L. Neumann, and Reinhard Bendix, have reflected on and accounted for their experiences. The task is much more difficult when scholars do not realise the impact of these experiences and do not reflect on them. This could concern those scholars (including many lawyers) who mostly remain silent about their experiences.

Tuori, however, emphasises that even for social science scholars who did process the experience openly, the assessment of what the process of exile meant to them is fraught with difficulties. ${ }^{23}$ After scrutinising the life and scholarship of the Roman law scholar Fritz Schulz, Tuori asks, 'his work shows what can be described as a textbook case of the exile process. Or does it??24 Therefore, it is clear that any change that could possibly take place in the conditions of exile or because of the exile process is complex and very hard to classify. ${ }^{25}$

For Söllner, such change is sometimes only visible in the microsphere, in the directions of scholars' personal careers ${ }^{26}$ or in schools of thought that stayed together for a longer period, such as the New School for Social Research or the Frankfurt School in New York. ${ }^{27}$ In this chapter, therefore, we limit our analysis of the experience of displacement to direct accounts by the scholars. Such task seems to be more feasible in the case of currently displaced scholars, since the interview questions could address these changes and influences in real time. It proves much more difficult in the cases of the historical figures. Even though some of their accounts exist, they are very fragmented and escape any attempt at generalisation.

The second difficulty in our analysis is the relationship between the historical and contemporary narratives. In fact, the experiences of Jewish scholars - refugee scholars from Nazi Germany - were situated, and could not be compared with the situation of contemporary scholars. Indeed, mere exercise in comparison between the positions of historical and contemporary figures would provide a distorted and superficial image. For these two reasons, the accounts of historical figures mostly serve as background or a reference point for discussing the experiences of contemporary displaced scholars and academics at risk.

As a result, the experiences and stories discussed in this chapter do not conform to a conventional or normative discourse or narrative, which, according to Livholts and Tamboukou, is expected to '(a) [be] sequential and meaningful; (b) definitely human; (c) "re-present" experience, reconstituting it, as well as expressing it; (d) display transformation or change. ${ }^{28}$ On the one hand, accounts of exile experiences by the historical figures are mostly absent or fragmented and therefore difficult to translate into a coherent story. For instance, as Rosemary Bodenheimer, the daughter and biographer of law scholars Edgar and Brigitte Bodenheimer, writes, 'Edgar's post-war silences were widely shared by people everywhere on the spectrum of guilt, shame, survival, and suffering. ${ }^{29}$ On the other hand, the silence may not only be caused by the experiences themselves, but also occur at the level of the available research materials. They could be, for instance, produced by the archival work that can leave the researcher with nothing but fragments: 'you find nothing in the Archive, but stories caught half way through the middle of things: discontinuities. ${ }^{30}$ 
At the same time, the interviews with four contemporary displaced scholars contain accounts of scholarship in the making. Even though the interviewed scholars were eager to reflect on the development of their work, the change could most likely only be seen from the perspective of time. A linear and 'complete' narrative often emerges from accounts given at the end of life. In the words of John Herz, a legal and International Relations scholar, who fled from Nazi Germany to the US:

Telling this oral history of my life has made me think of writing memoirs, once my present projects are completed. But it would not be an autobiography: I don't think that my life as such would be of sufficient interest. It would, rather, be the story of how my views about the world developed, that is, the story of the enfolding of the world view, or world views, or Weltanschauungen, of one whose life was pretty much devoted to thought, and whose experience, covering the better part of this century, was perhaps paradigmatic of what of many others who labored in this vineyard. ${ }^{31}$

For that reason, when giving the accounts of the experiences of scholars, we followed Livholts and Tamboukou, who emphasise that,

[i]n order to be able to listen to these stories it is important that narrative researchers as well as all other listeners, suspend their preconceived narrative norms and rather treat these stories as invitations to listening in new and creative ways. ${ }^{32}$

Listening to the characters 'as they enter the stage' is therefore a part of authoring. ${ }^{33}$ Of course, these listening skills cannot be disconnected from the position from which one is listening and, then, speaking. Indeed, according to Arendt, 'in order to think politically as well as philosophically, you need a position from where to speak, you need to acknowledge your involvement in the human web of relations: you are always in the world with others' ${ }^{34}$

Our analysis in this chapter constitutes such a listening exercise, in which the experience of displaced scholars or scholars at risk and the experience and positionality of the authors as female migrant legal researchers have come together and produced a particular narrative. This narrative is born out of a dialogue between two groups of scholars: historical and contemporary figures, where the biographies of historical figures oriented the interview questions. Importantly, regardless of the predominating silences amongst law scholars, most of the historical figures cited below had a background in law. Some of them, such as John Herz or Franz Neumann, had to rebrand themselves and take positions in political science or International Relations departments. ${ }^{35}$

At the same time, the issues that arose from the interviews served as an inspiration for investigating the biographies of the historical figures. In particular, the contemporary scholars were asked the questions that we could 


\section{4}

not ask the exiled scholars. The narrative produced in this chapter is an account of this interaction between these historical and contemporary figures, filtered through the authors' own positionality and experience. In particular, whereas the authors have not experienced displacement themselves, they recognise the experience of precarity brought up in the interviews as lawyers, who are migrants and researchers. Such experience is, however, not limited to displaced or migrant scholars; it is the characteristic of all modern academia $^{36}$ or life itself. ${ }^{37}$

In this chapter, we address the emotional aspects of scholarly work, contributing to a growing body of research on both migrant emotions and academic emotions, in particular emotions in legal academia. Emotions described as 'simultaneously cognitive, motivational and physiological experience' are mutually constitutive of social reality ${ }^{38}$ and are crucial for building collectives and belonging. ${ }^{39}$ They concern academic identity and belonging. The ability to relate to pain is, according to Vatansever, a way to turn a painful experience into a reconstructing one, including intellectual and academic development. ${ }^{40}$ In addition, emotions (intertwined with cognitive functions such as reasoning and rationality) are the important elements of legal research. ${ }^{41}$

\section{Experience of displacement and academic work: silences and voiced accounts in conversation}

By listening to the interviews and reading the biographies and accounts of the historical figures, we identified the three most meaningful and unifying elements. The first element is the experience and conditions in the country of exile, refuge, or residence. The second element is the development of the scholar's academic career, in particular, their scholarly identity. The third and last element is the issues related to human rights, justice, and the need to act. In this part, we will analyse these three elements.

\section{Experiences and conditions in the country of exile and refuge}

It is important to point out that legal scholars' experience of exile, both in the past and in the present, seems to be more emotional than merely academic or scholarly. In other words, the scholarly work is affected by the multifaceted positionality of the researchers and their reaction to the world. As John Herz remarked in one of the interviews with his biographers:

The world became a theatre of the absurd. Suicide would probably have been the logical next move, and I considered it from time to time. However, I was still too young for such a radical step. One thing, however, emerged: a growing interest in domestic and, above all, international politics. My complete resignation was no longer appropriate. If not from within, fascism might perhaps still be destroyed from without. To my continuing interest in theory, therefore, was added a practical interest in action. $^{42}$ 
Similarly, the impact of emotions on the experiences of the contemporary scholars is visible in the remarks of one of the interviewees, who reminds us that the fear and the shock caused by the reality of not being able to go back home any more haunts you and stays with you forever (Scholar 1). Scholars 1 and 4 use the metaphors of 'stages of grief' and 'a sense of grief', respectively, for dealing with their emotions after realising that they are no longer able to go back to their home countries. Scholar 1, first, describes not being able to go back home anymore as a 'joke', 'it is not real, it is just a phase, but later you realise that no, this is not a phase, things are real'. After noticing how real the fact that one cannot go back is, according to all the interviewees, 'a state of uncertainty about the future strikes the mind', and 'you start to feel the burden that you should do something, that one needs to change the situation in the home country'. Scholar 2 empathises on this fear and uncertainty about the future:

I really remember that shifting my mind actually, in just like [...] So, we signed the petition and then soon after Erdoğan said that I'm not gonna live like, like this, and everybody will pay for it. Like a couple of months later, I was really realising that I was getting into an exile mode in my mind.

Together with the sense of grief, the scholars have to deal with other negative emotions such as 'guilt,' 'aimlessness,' and some levels of identity crisis related to the concepts of 'home' and 'roots.' They feel guilty that they caused problems for their family members back home. In addition, they feel empty and aimless, since they cannot connect to any particular place as their 'home' and a figurative answer to the question 'where am I from?' Struggling with these feelings was a trend easily understood in the course of all the interviews, especially in the case of Scholar 2, who, in response to the question, 'What does home mean to you?' said, 'I don't know [...] this is a question that never leaves you alone. I feel guilty that I have put my family back home in trouble. The whole family is at risk.'

Notwithstanding the feelings of grief, guilt, and uncertainty in the aftermath of realising that they could not go back home, the scholars experienced a swing of emotions ranging from misery and hopelessness to a complete sense of determination and hope for the future in the country of refuge. One possible reason for this change is the scholars' expertise and being valorised in their countries of residence. As all the interviewees mentioned, at some point in their interviews, they felt a sense of 'self-value.' This feeling came out of their academic institutions recognising their achievements: 'finally, I got somewhere where my expertise and my thought is not wasted, is wanted,' said Scholar 3, who had worked as a human rights lawyer before leaving their home country.

In addition, scholars found it helpful to realise that through their academic work in their countries of refuge or new residence they could have some influences on their environment or contribute to positive changes. It seems that 
people targeted by persecution and oppression in their home countries feel that they have something better and bigger awaiting them, so they go through the path of migration in the hope of achieving something greater. Scholar 1 expressed this mixture of thoughts and emotions: 'It is not all that black - we can make changes, we can open new horizons, we can go to new lands.'

In the interviews, we came across very different attitudes towards the countries of refuge or residence, and, hence, different experiences of lives in displacement in the context of academic work. It is obvious how differently host countries have made a hospitable or hostile environment for the scholars and, based on that, how differently scholars perceive the same country of residence. While Scholar 3 praised academia in their country of residence as a very hospitable environment to grow as a scholar, Scholar 2 about the same country said, it 'is a very difficult place; white male [scholars] dominate, taking control in academia. Positions [are] for Europeans. Discrimination is still there.'

As opposed to Scholar 2, Scholar 3 appears to be very much included in the academic environment of the country of residence. They state, 'they took me under their wings,' complementing their university colleagues and appreciating the inclusiveness of the academic environment. Like Scholar 3, Scholar 1 also admits how a hospitable academic atmosphere in their respective countries of exile helped them feel included as a member of the community, which provided them with a suitable environment to grow gradually as a scholar.

Another important aspect of the conditions of exile and displacement for legal scholars in this study is the influence of the change in their legal residence status (Scholar 1). At the same time, not being able to speak the language of the country of residence and not holding the legal status of a citizen create immense obstacles for the scholars in finding suitable positions related to their fields of expertise. Scholars 2 and 4 complained how they had to spend some years on irrelevant jobs, while they were learning the language and until they could find funding to support their academic career. Additionally, Scholars 2 and 4 emphasised that not knowing the language and the lack of legal status (not being a citizen of the country of displacement or the EU) was a reason for their not getting the kind of academic positions similar to what they used to hold in their countries of origin.

The emotions felt towards the home country or in connection with displacement, ${ }^{43}$ as well as diverse experiences in the host countries and universities, raise some broader political questions. Amongst these issues, we could think of access to rights, discrimination, and othering based on gender, age, country of origin, legal status, and other issues related to and influencing migration and refugee management more broadly. These issues have been widely discussed within the field of migration studies. ${ }^{44}$ At the same time, they also reflect the discussion on the conditions of contemporary neoliberal academia. ${ }^{45}$ These experiences point to the situatedness of the experience of displacement and the role of intersectionality in the construction of social realities. ${ }^{46}$ 


\section{Academic career development: scholarship and scholarly identity}

The question of scholarly identity in displacement became one of the most interesting ones in this study. Both historical and contemporary figures have extensively discussed this question. ${ }^{47}$ However, it should be noted that depending on their legal, academic, political, or other situation, scholars grapple with this question differently. For example, for Arnold Brecht (former high-level bureaucrat in the German Chancellery and in the Prussian Government, professor of law, and one of the first members of the 'University in Exile'), ${ }^{48}$ who regularly visited Germany and was involved in anti-Nazi activities in the late 1930s, the label 'exile intellectual' was not desirable or it was even dangerous. In his response to a request to speak on a radio programme as a 'distinguished exile,' he wrote:

Allow me, however, to state frankly that I dislike to be listed in a separate group of "distinguished exiles". I have never suffered any dramatic persecution so as to deserve the specific halo of that word. I am just a German who takes a stand for a minimum program of liberty, wherever he goes. I hate the grouping of Germans in this country into exiles and others, because it falsifies my position and separates me likewise from Germans and from Americans. ${ }^{49}$

Interviewees' answers to the question on their scholarly identity in displacement ranged from preferring to see oneself as a refugee rather than an academic (Scholar 4) and not identifying oneself as being in exile (Scholars 1 and 2) to ending with reluctant admittance of one's own position as a scholar (Scholar 3). A common thread in the interviews is the impossibility of practising or teaching law in the scholars' home countries because of the political situation and the longing to do so in the country of current residence, which is often not possible or very difficult. Out of four interviewees, two pursued a doctoral degree in law after leaving their home countries, because they were not able to practice law in their countries of exile or new residence (Scholars 1 and 3). As they remarked, they would not necessarily have done a doctoral degree without practicing law if they had not left their home countries.

As a human rights activist, Scholar 3 was forced to leave their country of origin. In their home country, outside legal practice, they were involved in lobbying and advocacy for human rights. Their advocacy work had inspired them to pursue a doctoral degree with a focus on what to do when the government is gone and on how the next democratic government could deal with the existing human rights violations. However, they faced many limitations on their advocacy work including some underlying causes for human rights violations such as corruption. As a result, Scholar 3 found in Europe a place for researching human rights. However, this scholar, who started to work on fundamental and human rights issues out of both passion and life circumstances, explained that the lack of opportunity to practice law in Europe has made them 'really sad': 
My choices became limited; [it is] difficult to practice law in other countries, so academia is [the] place to go. Otherwise, I would not have become a scholar. [...] I can do more than just writing about the law. [...] I drifted towards the academy because I had to adapt very quickly. I had to do it very quickly so that was probably the only option for me at the time.

They believe that they ended up being a scholar 'by default, reluctantly', 'I don't think there is any way out. I am just going to be a scholar now.'

At the same time, despite the lack of opportunity to practice law, Scholar 3 appreciates the development of their legal research skills and the fact that they are writing and publishing and others are citing their academic work. This makes them appreciate their position as a scholar:

What I learned or benefited from is the methodology side, the methodology aspect. This is something you really emphasise here and it actually helps, and when it comes to the legal research, when it comes to shaping your argument, being in academia or if I come back to my legal practice, it will also help me. So, I've learned a lot when it comes to the issues of methodology.

In spite of this appreciation, they continue, "that is the kind of thing scholars do. So, I am wearing different hats. I can wear that hat as a scholar, an exile scholar, but I am more comfortable not wearing any hat at all.'

Scholar 1 made similar connections with regard to not being able to practice law in Europe. As a lawyer trained in a very different legal system with different understanding of law, Scholar 1 is still struggling with the concept of law. They understand why there are so many restrictions on practising law for those trained in different legal systems; yet, they connect with Scholar 3 in how this fact has limited their career choices. Notwithstanding their complaints about barriers to legal practice for exiled or refugee lawyers, Scholar 1 recalls that what displacement has offered them is removing barriers to their thinking:

Here, in Europe, I am allowed to think, to think for myself, to think on my own. This is something I'm not used to. I had so many questions as a law student back in my home country, but it was not free enough or not safe enough to ask those questions in the classes.

Scholar 1 continues:

The sense of censorship is so embedded in you that it makes a glass wall for your thoughts. Even in the free world, we are still living inside the glass of censorship, especially coming from a legal system that is very dogmatic and positivist and makes law students accept the law as it is.

Similar to other interviewees, human rights law is the field of law in which Scholar 1 finds their genuine scholarly interest. As they said, with their background and values, they could not be a black letter lawyer, 
[a]nd now, this human right has become so much part of me that even if today I go back for any reason, I don't think I would give up on that. You know the idea of working for human rights, in the field of human rights, for the betterment of the society and the system. I would not give up on that.

Similarly, Scholar 2, for whom exile and leaving home meant losing access to their research field and data, recognises a strong link between their scholarly identity and the issues at stake in their home country. Scholar 2 states,

I am working on Turkey again, but in a different way, which is also something of the biggest impact on me. I lost my field site. Big time. And so, I must, of course, rethink what I can do from where I am, what kind of data I can still collect if I want to work on Turkey.

Scholar 2 acknowledges, however, that the academic career has become less important for them since leaving their home country:

But I also saw at that time I started caring less about my academic position, because I am also seeing people are sacrificing so much already, they lost their jobs, people do whatever they can find, working in construction. I was lucky I was already out, and I could stay wherever I am and then try to be rooted a little bit more. So at least I am quite lucky, I know that.

Scholar 4, who focused extensively on the paradoxes of their academic career in the country of refuge, referred to both emotional and practical aspects of being a refugee, but recognised that these could be also rooted in the situation in the country of origin, and in a general structure of neoliberal academia. First, the scholarly identity of Scholar 4 seems to be undergirded by uncertainty and ambiguity about the law and being a lawyer, both in the country of origin and in the country of refuge. They tried to work as lawyer in their home country, they even passed the bar exam and practiced for a year, but they were not able to continue because of corruption and the climate at the local courts. In addition, after the Arab uprisings started, Scholar 4 and their colleagues at the universities were forbidden to talk about human rights. They remember that, with a group of friends, they tried to think about how they, as lawyers, could talk about the crimes committed in Syria and not get arrested, and how they could help students who were arrested.

After fleeing to Europe, Scholar 4 was happy that they could finally come back to what they loved (research), but they were also shocked by their inability to speak the language of the country of refuge, coupled with the fact that the situation in their home country affected their academic career significantly. We quote Scholar 4 extensively because they illustrate the scope of problems displaced scholars need to deal with, including the lack of language skills, inability to focus on work because of worrying about the fate of their families and friends, and the difficulty of competing with other academics: 
Yeah, getting back to what you like to do, but you feel you are not - how to say, I don't speak [the language]. If you don't speak [the language], and you are a lawyer, you couldn't ... [uh] ... compete at all. And the second problem was that my head was not really - I could not focus. I must learn the language. I must overcome what I hear every day about my family in Syria; so, I have my mother and my brother and my sister and even not having my family there, I still think about my country. I don't want to work where I feel I couldn't do it. I am working very slowly. Most of the time, I attend [the language] courses. And, this is another problem that I don't progress a lot in [the language] courses, because I don't do enough for it. And, I don't progress enough in my work, because it is research, only research, of course, I couldn't teach. I've spent, let's say, eight years of my life, since the war started, doing nothing, just living the, let's say trying to overcome the obstacles of being from a country, which is at war. Eight years is too much. Because in eight years you could publish many books, you could - not a lot, but two books, one book, ten articles, no, let us say, four articles. I couldn't do that. This is a problem, of course, I shouldn't compare, but at the same time, I should think about my future, where is it I'm going. Everybody - I mean my [boss] is encouraging me to stay in law. But, for me, I don't see myself anymore here in law.

In response to being asked, why they do not see themselves pursuing law despite having a position in academia with a relatively good working condition, Scholar 4 said that they still found it somewhat difficult to adapt:

They are trying to give us the conditions. Like to put a tree, to plant a tree in a different, to put a tree in that is not in this climate and to do everything and trying make it grow but really, this tree is not growing. The tree either is dying or trying to survive, but not really having the fruit that you would like to see and eat.

Scholar 4 stresses that the condition for academic work, or any work for that matter, is the mental wellbeing:

First of all, are you really feeling normal? Are you sleeping well? Are you thinking in a positive way and not negative? Can you separate your problems from the problems of people in the area you are coming from?

As they mention, these obstacles affect not only themselves but also others, including their spouse, who is also a scholar, 'we have to think about different issues, we forget about when that issue is ourselves.'

To be sure, these experiences could directly affect one's research project. While three out of four interviewed scholars, particularly those, who had started their academic careers 'in exile,' had the opportunity to focus on their own research topic, for Scholar 4, doing so has been very difficult. Scholar 4 has had this opportunity, but recognised the loss of time due to not being 
able to work anymore, first in Syria, and then in the country of refuge. For the reason that their lack of language skills prevented them from being fully involved in the scholarly community in the host state, they concentrated in their current research on following and commenting on the Syrian conflict. However, as they claimed, this felt like a waste of their expertise. Therefore, they are considering changing career and giving up on academia.

When it comes to scholarly identity, Scholar 4 feels more like that of a refugee than a scholar does. Scholar 4 stopped being a scholar once they left Syria. As they say,

I couldn't be scholar here anymore although I am trying. But the refuge started and everything is done to me because I am a refugee. [...] I feel like a refugee more than I feel a scholar. I do not feel I am a normal person; I am a refugee actually.

The accounts in this section point again to the precarity of displacement linked with the politics of migration and refugee protection, which play an important role in the dissolution of old identities and the creation of new ones, such as 'refugee identity. ${ }^{50}$ Often refugee identity prevails over the scholarly, especially when structural supports and labels such as 'Scholars at Risk' highlights the individual's displacement more than their scholarly work. Despite the multiple critiques and the increasing precarity of academic knowledge, western academia has provided a way for many displaced scholars to valorise their labour and to obtain a position from which they could voice their concerns and be listened to. ${ }^{51}$

\section{Human rights, justice, and the need to act}

The need to act to counter the observed and experienced human rights violations is a common thread in the lives of both the historical figures and the interviewed scholars. In many cases, this is a response to their own experiences of suddenly turning from a scholar or a lawyer into a criminal or an outlaw. Edgar Bodenheimer, who became a law professor in Salt Lake City and later in Davis, CA, USA, considered his position as 'a lawyer disbarred by a "law", [to be] both absurd and illegal.' This strongly affected the development of his theory of jurisprudence, based on natural law principles. ${ }^{52}$

For this reason, scholars have often engaged besides their intellectual and scholarly work, in political activism linked with subjects beyond their main areas of research. Therefore, their identity is shaped not only through their scholarly work, but also through linking it with efforts to bring about changes. As Franz Neumann, who became a professor of political science and law at Columbia University in the US, said:

The intellectual is (or should be) the consciousness of the society in the prevailing time of history. His task is to measure how much (or little) society practises liberty. In a sense, the intellectual is frowned upon, because the role of the consciousness is rarely comfortable, especially in politics. ${ }^{53}$ 
Similarly, as Scholar 1 explains, 'here, the question of identity comes to light. Establishing identity, getting connected to who I am or who I want to be.' On the one hand, the need to act is often linked with 'the guilt of not being able to do much.' The interviewed scholars (for instance, Scholar 2) mentioned that they often felt guilty about leaving their home countries and not being able to make any change there.' This point is visible in some research on 'migrant emotions.' ${ }^{54}$

On the other hand, some scholars are more hopeful, and, in their work, they mainly focus on developing solutions for the time when the situation changes at home. They want to be ready. As Scholar 3 explains, "even though we are in a troubled situation and things are not going as they should, who knows, maybe things will improve at home.' They are hoping to go back home to make changes. They display a strong sense of obligation towards their homes, especially towards politics.

In addition, while the interviewed scholars feel the urgency to be involved, they cannot comprehend the lack of response to the need to act in the country of refuge. As Scholar 4 notices, 'I find strange here in this country that you could talk about what you want, in a peaceful way. But nobody talks.' When asked why they think so, they answer:

Because they are busy. They are busy. Busy, busy, busy. People are really getting out in this country from the morning and getting back home in the evening. They are tired. They want to sleep. Wake up; go to work like a machine. When you have a little time to socialise, you don't want to socialise, you want to relax. And, this is the plan of politics. Makes you busy, busy, busy not to think, that they couldn't object to you. You know there are problems, but you don't have time to organise the - let's say a group of people to say we don't want that. That is a job of people who don't have a job.

Scholar 4 expressed some difficulties in understanding that people have the freedom to protest and organise and to influence their conditions of life, but they do not: 'but when you have the chance, you don't do it. We didn't have the chance and we did it and we were killed.'

These accounts are a sharp critique of contemporary academia and liberal democracy more broadly. At the same time, they highlight the need for community building and a sense of solidarity 'in order for a new form of intellectual subjectivity to arise out of imposed precarity. ${ }^{55}$

\section{Discussion}

The accounts given by the scholars here point to the crucial place of emotions, experiences, and broader scholarly positionality in their research. This not only concerns the content of their academic work, but, more importantly, the overall ability to work, to build or maintain a scholarly identity, and to create new forms of solidarity and community. Feeling included in various 
aspects of life seems to be crucial to creating sound conditions for scientific work, with a stable legal status that guarantees security, and knowledge of the language. The interviewees also stress the significance of feelings of selfefficacy and the importance of one's actions for society, in particular in one's home country. In contrast, the feeling that one's position is based on humanitarian rather than professional considerations has often been problematic. As Hannah Arendt wrote in 1943, '[i]f we are saved, we feel humiliated, and if we are helped, we feel degraded. ${ }^{56}$

In addition, the interviewees feel disadvantaged by the time wasted and their inability to compete with scholars who did not have to experience exile and a lack of academic freedom. These feelings clash with understanding their own secure position and the gratitude for the help they received. As Asli Vatansever highlights:

Whether the experience of exile ends up affecting the person in a paralyzing or empowering way, very much depends on a "de-privatization of misery". The encounter with precariousness needs to be dissociated from the highly individualised connotations of exile and conceived as a common denominator with other forms of insecurity as experienced by different segments of the reserve army of labor. ${ }^{57}$

For us the authors, perhaps the key finding of the interviews is the importance of the emotional aspect of displacement and scholarly work. In this sense, our study contributes to a growing body of academic work on migrant emotions and academic emotions, in particular, emotions in legal academia. Despite growing recognition of the important role of emotions within various aspects of legal education, research on this topic remains scarce. In legal profession, 'thinking as a lawyer' has traditionally epitomised an approach without any emotions to legal problems or questions. ${ }^{58}$ However, the existing research points to the key role of emotions, which are intertwined with some cognitive functions such as reasoning and rationality, and hence are very important not only in legal practice, but in legal research. ${ }^{59}$

What has emerged from some of the interviews is, on the one hand, the need or often difficulty to cope with the need to compete, but, on the other hand, the inability to compete due to one's own experiences (which tap into existing discussions on wellbeing in contemporary academia, with its increased emphasis on performance and research productivity). As scholars of emotions in legal academia point out, one could notice a decrease in positive emotions (love of one's subject) and an increase in negative emotions such as stress and anxiety related to the increased focus on measurable output and performance. ${ }^{60}$

To conclude, this study clearly shows the emotional labour of academia in conjunction with the personal experiences that could have a significant impact on the scholarly life. None of these could be taken away from discussions on experiences of exile in scientific work. At the same time, the experiences of displaced academics need to be situated within general political discussions on 


\section{4}

migrant and refugee management and precarity in general. There are a lot to be learned from the experiences of displaced academics who are well situated to pose a critique of contemporary societies. New forms of identities and solidarities are needed that are rooted in shared vulnerability.

\section{Acknowledgments}

The authors express their gratitude to those who gave their time to be interviewed. Special thanks go also to Iida Silfverhuth for her tremendous help with sources in German. This work is part of the Academy of Finland funded Centre of Excellence in Law, Identity and the European Narratives (funding decision numbers 312431 and 336678).

\section{Notes}

1 Arnold Brecht, Letter to Anette Bushman, June 12, 1938. Arnold Brecht papers, The German and Jewish Intellectual Émigré Collections, SUNY Albany.

2 Livholts and Tamboukou, 2015, 121.

3 See, for instance, Fermi, 1968; Heilbut, 1997; Söllner, 1996a; Söllner, 1996b; Ash and Söllner, 1996; Coser, 1984; Krohn, 1993; Greenberg, 1987.

4 Tuori, 2020; Konuk, 2005; Camurri, 2014; Rösch, 2014; Berger and De Baets, 2016.

5 Konuk, 2005, 32; Burke, 2016, 39; Vatansever, 2020.

6 Tuori, 2020.

7 Jay, 1996, 215.

8 von Lingen, 2020.

9 von Lingen, 2020.

10 Vatansever, 2020; Özdemir, Mutluer, and Özyürek, 2019.

11 Fermi, 1968, 79.

12 Graham, 2002.

13 Ash and Söllner, 1996; Rösch, 2014.

14 In order to protect the identity of the interviewed scholars, we anonymised all the interviews. The country of origin is revealed only in case of countries with a big number of refugees. The country of current residence is not revealed in any case. We did not include information on the gender of the respondents although we are aware that the experience of refuge and being a scholar at risk seems to differ between male and female academics. In addition, we did not report nor reflect on other individual factors or personal attributions affecting the scholars' perspective.

15 See, for instance, Söllner, 1996b; Ash and Söllner, 1996; Konuk, 2005; Tuori, 2020.

16 Neumann, 1961, 20.

17 Neumann, 1961, 20.

18 Söllner, $1996 \mathrm{a}, 84$.

19 Vatansever, 2020, 148.

20 Vatansever, 2020, 148.

21 Butler, 2006, 31.

22 Söllner, 1996a, 146-147. (Translation from German by Ida Silfverhuth.)

23 Tuori, 2020, 65.

24 Tuori, 2020, 75. 
25 Tuori, 2020, 75.

26 Söllner, 1996a, 86.

27 Söllner, 1996a, 92.

28 Livholts and Tamboukou, 2015, 40.

29 Livholts and Tamboukou, 2015, 119.

30 Livholts and Tamboukou, 2015, 67.

31 Remarks typed by Prof. Spalek for SUNY Albany project. John Herz papers, The German and Jewish Intellectual Émigré Collections, SUNY Albany.

32 Livholts and Tamboukou, 2015, 100-101.

33 Livholts and Tamboukou, 2015, 54.

34 Livholts and Tamboukou, 2015, 128.

35 Kmak, 2019.

36 Vatansever, 2020.

37 Butler, 2006.

38 Boccagni and Baldassar, 2015, 73-74.

39 Ahmed, 2004, 25, 39.

40 Vatansever, 2020, 148.

41 Seear, Bliss, Galowitz, and Klein, 2019.

42 Stevens, 2018, 283.

43 Boccagni and Baldassar, 2015.

44 Gozdecka and Kmak, 2018; Fiddian-Qasmiyeh, 2020; Anthias, 2020.

45 Vatansever, 2020; Özdemir et al., 2019.

46 Anthias, 2020.

47 Vatansever, 2020.

48 Friedlander, 2019.

49 Arnold Brecht, Letter to Anette Bushman, June 12, 1938. Arnold Brecht papers, The German and Jewish Intellectual Émigré Collections, SUNY Albany.

50 Kothari, 2020.

51 Many thanks to ElSayed Elsahemy for this point.

52 Bodenheimer, 2016, 29.

53 Luthardt and Söllner, 1989, 101.

54 Boccagni and Baldassar, 2015.

55 Vatansever, 2020, 137.

56 Arendt, 2007, 268

57 Vatansever, 2020, 8.

58 Seear et al., 2019, 1.

59 Seear et al., 2019, 1.

60 Jones, 2018, 450, 475.

\section{References}

Ahmed, Sara. 2004. "Collective Feelings: Or, the Impressions Left by Others." Theory, Culture \& Society 21, no. 2: 25-42.

Anthias, Floya. 2020. Translocational Belongings: Intersectional Dilemmas and Social Inequalities. Oxford and New York: Routledge.

Arendt, Hannah. 2007. "We Refugees." In The Jewish Writings, edited by Hannah Arendt, Ron H. Feldman, and Jerome Kohn, 264-274. New York: Schocken Books. Ash, Mitchell G., and Alfons Söllner. 1996. Forced Migration and Scientific Change: Émigré German-Speaking Scientists and Scholars after 1933. Cambridge: Cambridge University Press. 
Berger, Stefan, and Antoon De Baets. 2016. "Reflections on Exile Historiography." Storia della Storiografia - History of Historiography 2016, no. 1: 11-26.

Boccagni, Paolo, and Loretta Baldassar. 2015. "Emotions on the Move: Mapping the Emergent Field of Emotion and Migration." Emotion, Space and Society 16: 73-80.

Bodenheimer, Rosemary. 2016. Edgar and Brigitte: A German Jewish Passager to America. Tuscaloosa: University of Alabama Press.

Burke, Peter. 2016. "Silver Lining: On Some Intellectual Benefits of Exile." Storia Della Storiografia, Storiografia - History of Historiography 69, no. 1: 39-48.

Butler, Judith. 2006. Precarious Life: The Powers of Mourning and Violence. London: Verso.

Camurri, Renato. 2014. "The Exile Experience Reconsidered: A Comparative Perspective in European Cultural Migration during the Interwar Period." Transatlantica. Revue d'études Américaines. American Studies Journal 1. doi:10.4000/ transatlantica.6920.

Coser, Lewis A. 1984. Refugee Scholars in America: Their Impact and Their Experiences. New Haven: Yale University Press.

Fermi, Laura. 1968. Illustrious Immigrants: The Intellectual Migration From Europe 1930-1941. Chicago: The University of Chicago Press.

Fiddian-Qasmiyeh, Elena. 2020. Refuge in a Moving World: Tracing Refugee and Migrant Journeys across Disciplines. London: UCL Press.

Friedlander, Judith. 2019. A Light in Dark Times: The New School for Social Research and Its University in Exile. New York: Columbia University Press.

Gozdecka, Dorota A., and Magdalena Kmak. 2018. "Law and the Other." No Foundations: Interdisciplinary Journal of Law and Justice 15: i-ix.

Graham, Kyle. 2002. "The Refugee Jurist and American Law Schools, 1933-1941." American Journal of Comparative Law 50, no. 4: 777-818.

Greenberg, Karen J. 1987. The Mentor Within: The German Refugee Scholars of the Nazi Period and Their American Context. New Haven and London: Yale University.

Heilbut, Anthony. 1997. Exiled in Paradise: German Refugee Artists and Intellectuals in America from the 1930s to the Present. Berkeley, Los Angeles, and London: University of California Press.

Jay, Martin. 1996. The Dialectical Imagination: A History of the Frankfurt School and the Institute of Social Research, 1923-50. Berkeley: University of California Press.

Jones, Emma. 2018. "Transforming Legal Education through Emotions." Legal Studies. The Journal of the Society of Legal Scholars 38, no. 3: 450-479.

Kmak, Magdalena. 2019. "The Impact of Exile on Law and Legal Science 1934 1964." In Roman Law and The Idea of Europe, edited by Kaius Tuori, and Heta Björklund, 15-34. London: Bloomsbury.

Konuk, Kader. 2005. "Jewish-German Philologists in Turkish Exile: Leo Spitzer and Erich Auerbach." In Exile and Otherness: New Approaches to the Experience of the Nazi Refugees, edited by Alexander Stephan, 31-48. Bern: Peter Lang.

Kothari, Uma. 2020. "Colonial Imaginaries, Colonized Places." In The Routledge Handbook of Place, edited by Ares Kalandides, Uma Kothari, and Tim Edensor, 88-90. London: Routledge.

Krohn, Claus-Dieter. 1993. Intellectuals in Exile: Refugee Scholars and the New School for Social Research. Amherst: University of Massachusetts Press.

von Lingen, Kerstin. 2020. "Legal Flows: Contributions of Exiled Lawyers to the Concept of 'Crimes Against Humanity' During the Second World War." Modern Intellectual History 17, no. 2: 507-525. 
Livholts, Mona, and Maria Tamboukou. 2015. Discourse and Narrative Methods. Thousand Oaks, CA: SAGE Publications Ltd.

Luthardt, Wolfgang, and Alfons Söllner. 1989. Verfassungsstaat, Souveränität, Pluralismus - Otto Kirchheimer Zum Gedächtnis. Oplade: Westdeutscher Verlag $\mathrm{GmbH}$.

Neumann, Franz L. 1961. "The Social Sciences.” In The Cultural Migration: The European Scholar in America, edited by Franz L. Neumann, Henri Peyre, Erwin Panofsky, Wolfgang Köhler, and Paul Tillich, 4-26. New York: A. S. Barnes.

Özdemir, Seçkin, Nil Mutluer, and Esra Özyürek. 2019. "Exile and Plurality in Neoliberal Times: Turkey's Academics for Peace." Public Culture 31, no. 2: 235-259.

Rösch, Felix. 2014. Émigré Scholars and the Genesis of International Relations a European Discipline in America? London: Palgrave Macmillan.

Seear, Kate, Lisa Bliss, Paula Galowitz, and Catherine F. Klein. 2019. "Exploring the Role of Emotions in Clinical Legal Education: Inquiry and Results from an International Workshop for Legal Educators.” The Law Teacher 53, no. 4: 79-98.

Söllner, Alfons. 1996a. Deutsche Politikwissenschaftler in Der Emigration. Studien Zu Ihrer Akkulturation Und Wirkungsgeschichte. Mit Einer Bibliographie. Wiesbaden: VS Verlag für Sozialwissenschaften.

Söllner, Alfons. 1996b. "From Public Law to Political Science? The Emigration of German Scholars after 1933 and Their Influence on the Transformation of a Discipline." In Forced Migration and Scientific Change: Émigré German-Speaking Scientists and Scholars after 1933, edited by Mitchell G. Ash, and Alfons Söllner, 246-272. Cambridge: Cambridge University Press.

Stevens, Tim. 2018. "Exeunt Omnes? Survival, Pessimism and Time in the Work of John H. Herz.” Millennium Journal of International Studies 46, no. 3: 283-302.

Tuori, Kaius. 2020. Empire of Law: Nazi Germany, Exile Scholars and the Battle for the Future of Europe. Cambridge: Cambridge University Press.

Vatansever, Asl1. 2020. At the Margins of Academia: Exile, Precariousness, and Subjectivity. Leiden. Brill. 